\title{
Greenland: Bringing Together Remote Sensing and Fieldwork
}

\author{
VICTORIA PARRY*, PETER NIENOW*, DOUGLAS MAIR** \& JULIAN \\ $\mathrm{SCOTT}^{* * *}$ \\ *Institute of Geography, University of Edinburgh, Edinburgh, UK **Department of Geography \\ and Environment, School of Geosciences, University of Aberdeen, Aberdeen, UK ***British \\ Antarctic Survey, Cambridge, UK
}

\begin{abstract}
With global land and sea temperatures rising, the importance of accurate monitoring of the world's ice sheets is increasing. Satellite radar altimetry can be used to measure elevation changes of ice sheets from which mass balance can be derived. In the percolation zone of ice sheets, summer melt which percolates into the snowpack and refreezes causes a re-distribution of mass through densification, which can result in elevation changes which are not representative of changes in mass balance. We present data collected in the percolation zone of the Greenland Ice Sheet prior to and post the processes of summer melt, percolation and refreezing. Data from nine sites along two 1-km transects show that in 2004 there was a $31.6 \%$ increase in accumulation over the summer, but due to surface melting percolation and refreezing the average snowpack density increased by $26.2 \%$, resulting in only a $5.3 \%$ increase in elevation. Our results indicate that in areas of substantial seasonal melt and refreezing, densification rates must be accurately quantified if mass balance estimates are to be usefully derived from surface elevation change.
\end{abstract}

\section{Introduction}

Recent reports suggest global warming is unequivocal (IPCC, 2007) and that future warming will be enhanced at high latitudes. The Greenland Ice Sheet is the largest store of fresh water in the northern hemisphere and with the potential to raise sea level by $7 \mathrm{~m}$, the effects of warming on its future are of great concern. Additionally, increased runoff from the ice sheet may affect the strength of the ocean thermohaline circulation (Rahmstorf \& Ganopolski, 1999) with potential consequences for albedo and insulation feedbacks, related to the expanse of sea ice cover (Fichefet et al., 2003). Recent satellite observations indicate increased melt extent around the margins of the ice sheet (Albert, 2002; Steffen et al., 2004) and any future warming will affect mass balance through surface melting and runoff and possibly through ice dynamics (Zwally et al., 2002). With warming in the Arctic estimated to be twice that of the global average (Trenberth et al., 2007), 2-48C by 2040 (ACIA, 2005) there is a growing need to understand the likely response of the Greenland Ice Sheet to future climate change and to accurately monitor the current changes in mass balance.

Due to problems of scale, the only viable approach to monitoring ice sheet mass balance is through the use of satellite observations where the instruments require calibration, often through ground-truthing measurements. Accurate elevation changes over large areas of the polar ice sheets can be determined by repeat elevation measurements using satellite radar altimetry from which the mass balance can potentially be derived (Zwally et al., 2005). In the wet snow and percolation zones (Benson, 1962), however, seasonal changes in snow pack density result in a redistribution of mass through densification, meaning changes in surface elevation cannot be directly correlated with changes in mass. A decrease in elevation may be caused by surface melt, percolation and refreezing (Pfeffer et al., 1991), but with no mass loss (Braithwaite et al., 1994). Similarly, there may be positive summer accumulation in the form of rain or solid precipitation 
which melts and refreezes, thus causing an increase in snowpack density and mass, but little change in surface elevation.

The European Space Agency's 'CryoSat 2' mission, due for launch in 2009, is set to observe the polar regions through satellite radar altimetry. The aim of the mission is to measure elevation changes over land-based ice masses and interpret these changes in terms of mass loss or gain (ESA, 2007), thus improving our understanding of the response of the Earth's ice masses to climate change. In this paper we present field data collected from the percolation zone of the Greenland Ice Sheet to provide ground calibration for the satellite measurements to quantify the effect of the seasonal densification of near surface snow and firn on both surface elevation change and annual mass balance.

\section{Field Sites and Methods}

Fieldwork was undertaken at $* 1945 \mathrm{~m}$ elevation in the percolation zone of the Greenland Ice Sheet in the region of T05 (698 51N, 478 15W) on the EGIG (Expedition Glaciologique International au Groenland) line (Figure 1). In order to investigate variability in near-surface density and stratigraphy, snowpit measurements were made along two perpendicular transects. These were centred at T05, and an additional eight sites were investigated at intervals of $1 \mathrm{~m}, 10$ $\mathrm{m}, 100 \mathrm{~m}$ and $1 \mathrm{~km}$ from T05 along both transects: transect E, aligned in a east-north-easterly direction along the EGIG line towards the centre of the ice sheet (measurement locations E1, E2, E3 and E4), and Transect S, aligned in a south-south-easterly direction perpendicular to the EGIG line (measurement locations S1, S2, S3 and S4) (Figure 1).

To determine the seasonal change in density in the near-surface snowpack, measurements to characterise the snow/firn at each location were carried out during both the spring (pre-melt) and autumn (post-melt, percolation and re-freezing) of 2004. Snow pits were dug at each site down to the surface layer demarcating the end of the 2003 summer. In spring 2004 this layer was easily identified as a hard, icy and continuous layer located beneath the autumn hoar and was used as a reference surface for the bottom of all snow pits. Once this layer was identified in spring, ablation stakes were emplaced and used as markers to ensure this same horizon was used as a common reference for any depth change identified upon re-measurement in the autumn.

The stratigraphic recognition of all individual layers was determined visually (Colbeck et al., 1990) and using a semi-quantitative assessment of hardness (fist, finger, pencil or knife) carried out at $10 \mathrm{~mm}$ intervals down each profile. Density measurements were taken from each layer using one of three tubes of differing diameter. The largest tube that could be pushed into an individual stratigraphic layer was used to extract a known volume of snow $\left(57 \mathrm{~cm}^{3}, 161 \mathrm{~cm}^{3}\right.$ or $227 \mathrm{~cm}$ ) which was then weighed using a Newton balance to obtain density. Repeat measurements from stratigraphic layers were taken and averaged, and variability was found to be $2-3 \%$ for the large and medium sized tubes, and $17 \%$ for the small tube. Ice layers, lenses and pipes were also recorded in the stratigraphy. These ice features were allocated a density of $0.8 \mathrm{~g}$ $\mathrm{cm}^{-3}$ since it was not possible to measure their density directly in the field and the ice was often observed to contain bubbles.

\section{Results and Discussion}

The mean snowpack depth at the nine sites located within $1 \mathrm{~km}^{2}$ of T05 was $143.2 \mathrm{~cm}$ (standard deviation (s.d.) $4.0 \mathrm{~cm}$ ) in spring and $150.8 \mathrm{~cm}$ (s.d. 11.7) in autumn, yielding a mean summer increase in pit depth of $5.3 \%$ (Figure 2). The average density of the snowpack increased at all snowpits between spring and autumn (Figure 3). The mean snowpack density of all sites was $0.42 \mathrm{~g} \mathrm{~cm}^{-3}$ (s.d. 0.02) in spring and $0.53 \mathrm{~g} \mathrm{~cm}^{-3}$ (s.d. 0.04) in autumn, yielding a mean summer 
increase in density of $26.2 \%$. The average snowpit accumulation expressed as a depth of water equivalent (w.e.) therefore increased from $60.5 \mathrm{~cm}$ (s.d. 3.4), in the spring to $79.6 \mathrm{~cm}$ (s.d. 5.5) in the autumn, an increase of $31.6 \%$ (Figure 4 ).

These density increases result primarily from surface melting, meltwater percolation and subsequent refreezing at depth within the surface snow pack. The fact that densities increased substantially without any decrease in snow depth results from additional mass inputs as summer precipitation in the form of snow or rain. In addition, snow compaction during warmer summer temperatures also contributes to increased densities. This densification of the snowpack has implications for mass balance derived from elevation change. For example; for $1 \mathrm{~m}$ of snow, prior to melt, with an average density of $420 \mathrm{~kg} \mathrm{~m}^{-3}$, the w.e. is $0.42 \mathrm{~m}$. If the water equivalent remains constant (i.e. assuming no summer accumulation, or loss of mass), but the pack increases in density by $110 \mathrm{~kg} \mathrm{~m}^{-3}$ to $530 \mathrm{kgm}^{-3}$, the height of the snowpack will be reduced by $21 \mathrm{~cm}$ to $0.79 \mathrm{~m}$, which would be measured by satellite observations of elevation change, and could be misinterpreted as a loss of mass. Thomas et al. (2008) show that above $2000 \mathrm{~m}$, a $1 \mathrm{~cm}$ elevation change represents approximately a $1 \mathrm{Gt}$ mass change and given that the mass balance of the Greenland Ice Sheet above $2000 \mathrm{~m}$ is $+53 \pm 2 \mathrm{Gt} \mathrm{a}^{-1}$ (Zwally et al., 2005), neglecting to account for seasonal densification of the snowpack may result in significant errors. Our results indicate that a better calibration of the processes causing densification is required if improved estimates of ice sheet mass balance are to be derived from satellite radar altimeters. Braithwaite et al. (1994) show that firn density is related to annual melt and accumulation, and the decrease in melt with elevation subsequently causes a decrease in firn density with elevation. Li et al. (2007) also identify winter temperatures as having an impact on densification rates and with projections for winter temperatures to be warming at four times the global average (Christensen et al., 2007), longer term seasonal variations in densification processes will also become an important factor in mass balance measurements derived from elevation changes.

\section{Conclusion}

Measurements of snowpack depth and density, made before and after summer melting, were carried out in the percolation zone of the Greenland Ice Sheet in spring and autumn 2004. Results show that between spring and autumn 2004, there was an overall mass increase of the snowpack of $31.6 \%$ but that this is not reflected in the small average increase in snowpack depth of $5.3 \%$. This is due to the increase in mean snowpack density of an average $26.2 \%$ over the same period. Our results demonstrate that significant changes in density between seasons can result in very limited changes in surface elevation, despite significant changes in mass. Thus, in areas such as the percolation zone, where the snowpack shows substantial seasonal changes in density, mass balance estimates should not be based solely on observed changes in surface elevation.

\section{Acknowledgements}

This paper is a contribution to the validation of the ESA CryoSat. The work is funded by NERC through grant NER/O/S/2003/00620. Our thanks for assistance in the field go to Veit Helm, Sebastien Chastin and Carl Bøggild, and for logistical support go to Kristian Keller and Rene Forsberg of KMS and DNSC, Copenhagen, Malcolm Davidson of the European Space Agency, Robin Abbot of VECO Polar Resources, Kate Bar Friis of Kangerlussuaq International Science Support and the Danish Polar Centre. 


\section{References}

ACIA (2005) Arctic Climate Impact Assessment (New York: Cambridge University Press). Albert, M. (2002) Effects of snow and firn ventilation on sublimation rates, Annals of Glaciology, 35, pp. 52-56.

Benson, C. (1962) Stratigraphic studies in the snow and firn of the Greenland Ice Sheet, in:

SIPRE Research Report, Vol. 70, Cold Regions Research and Engineering Laboratory, Hanover, N. H., 93pp.

Braithwaite, R. J., Laternser, M. \& Pfeffer, W. T. (1994) Variations of near-surface firn density in the lower accumulation area of the Greenland Ice-Sheet, Pakitsoq, west Greenland, Journal of Glaciology, 40, pp. 477-485.

Christensen, J. H., Hewitson, B., Busuioc, A., Chen, A., Gao, X., Held, I., Jones, R., Kolli, R. K., Kwon, W.-T., Laprise, R., Rueda, V. M., Mearns, L., Menendez, C. G., Raisnen, J., Rinke, A., Sarr, A. \& Whetton, P. (2007) Regional Climate Projections, in: S. Solomon, D. Qin, M. Manning,

Z. Chen, M. Marquis, K. B. Averyt, M. Tignor \& H. L. Miller (Eds) Climate Change 2007: The Physical Science Basis. Contribution of Working Group I to the Fourth Assessment Report of the Intergovernmental Panel on Climate Change (Cambridge and New York: Cambridge University Press), pp. 902-903.

Colbeck, S. E., Akitaya, R., Armstrong, H., Grubler, H., Lafeuille, K., Lied, K., McClung, D. \& Morris,

E. (1990) The international classification for seasonal snow on the ground, in: Working Group on Snow Classification (Ed.) International Commission on Snow and Ice). Association of Scientific Hydrology, Wallingford, Oxon, 23pp.

ESA (2007) Cryosat -2 -Scientific Objectives. European Space Agency, http://www.esa.int/esaLP/ ESAW3J1VMOC LPcryosat 0.html (accessed 28 March 2008).

Fichefet, T., Poncin, C., Goosse, H., Huybrechts, P., Janssens, I. \& Le Treut, H. (2003) Implications of changes in freshwater flux from the Greenland ice sheet for the climate of the 21st century, Geophysical Research Letters, 30, 1911, DOI:10.1029/2003GL017826.

IPCC (2007). IPCC, 2007: Summary for Policymakers, in: S. Solomon, D. Qin, M. Manning, Z. Chen, M. Marquis, K. B. Averyt, M. Tignor \& H. L. Miller (Eds) The Physical Science Basis. Contribution of Working Group I to the Fourth Assessment Report of the Intergovernmental Panel on Climate Change (Cambridge and New York: Cambridge University Press), pp. 2-4.

Li, J., Zwally, H. J. \& Comiso, J. C. (2007) Ice-sheet elevation changes caused by variations of the firn compaction rate induced by satellite-observed temperature variations (1982-2003), Annals of Glaciology, 46, pp. 8-13.

Pfe er, W. T., Meier, M. F. \& Illangasekare, T. H. (1991) Retention of Greenland runo by refreezing - implications for projected future sea-level change, Journal of Geophysical Research-Oceans, 96, pp. 22117-22124.

Rahmstorf, S. \& Ganopolski, A. (1999) Long-term global warming scenarios computed with an effcient coupled climate model, Climatic Change, 43, pp. 353-367.

Steffen, K., Nghiem, S. V., Huff, R. \& Neumann, G. (2004) The melt anomaly of 2002 on the Greenland Ice Sheet from active and passive microwave satellite observations, Geophysical Research Letters, 31, L20402, DOI:10.1029/2004GL020444.

Thomas, R., Davis, C., Frederick, E., Krabill, W., Li, Y., Manizade, S. \& Martin, C. (2008) A comparison of Greenland Ice-sheet volume changes derived from altimetry measurements, Journal of Glaciology, 54, pp. 203-212.

Trenberth, K. E., Jones, P. D., Ambenje, P., Bojariu, R., Easterling, D., Tank, A. K., Parker, D., Rahimzadeh, F., Renwick, J. A., Rusticucci, M., Soden, B. \& Zhai, P. (2007) Observations: surface and atmospheric climate change, in: S. Solomon, D. Qin, M. Manning, Z. Chen, M. Marquis, K. B. Averyt, M. Tignor \& H. L. Miller (Eds) Climate Change 2007: The Physical Science Basis. Contribution of Working Group I to the Fourth Assessment Report of the 
Intergovernmental Panel on Climate Change (Cambridge and New York: Cambridge University Press).

Zwally, H. J., Abdalati, W., Herring, T., Larson, K., Saba, J. \& Steffen, K. (2002) Surface melt-induced acceleration of Greenland ice-sheet flow, Science, 297, pp. 218-222.

Zwally, H. J., Giovinetto, M. B., Li, J., Cornejo, H. G., Beckley, M. A., Brenner, A. C., Saba, J. L. \& Yi,

D. H. (2005) Mass changes of the Greenland and Antarctic ice sheets and shelves and contributions to sea-level rise: 1992-2002, Journal of Glaciology, 51, pp. 509-527. 


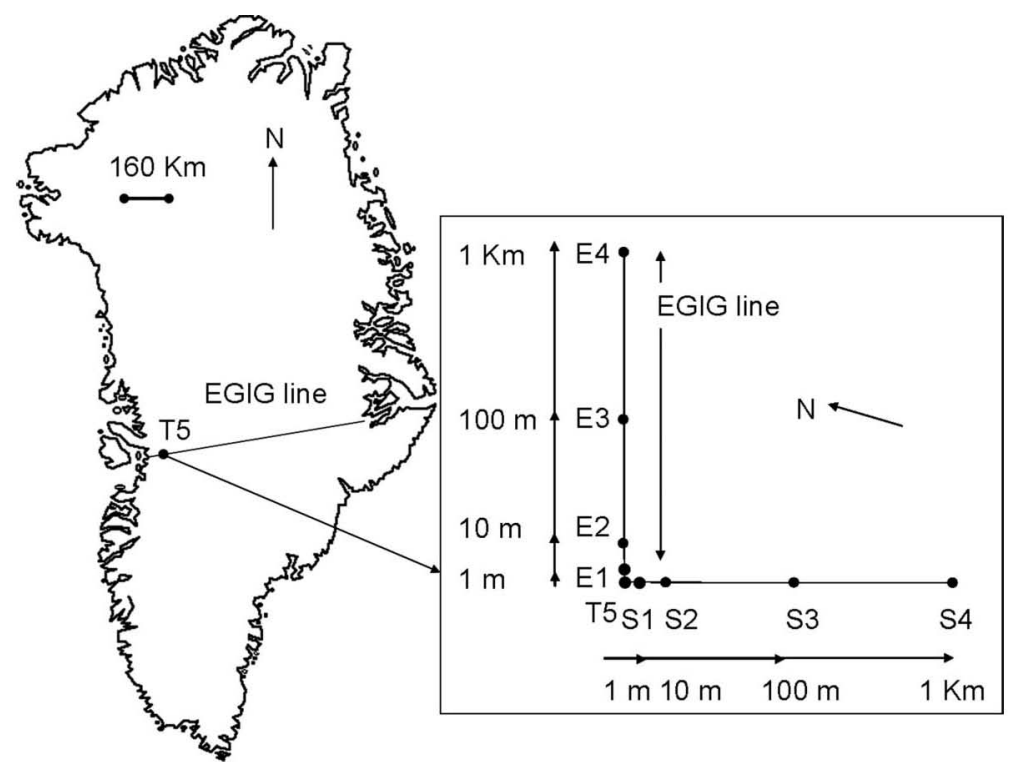

Figure 1. The location of the field site, TOS, on the EGIG line in Greenland and a schematic of the measurement locations 


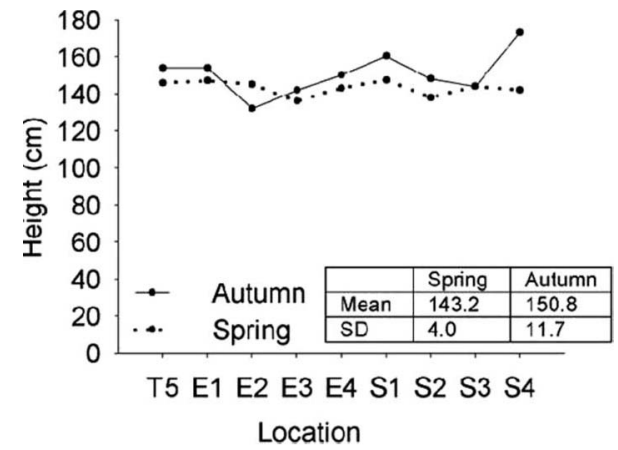

Figure 2. Spring and autumn 2004 snow depth above the end-of-summer 2003 surface for all snow pits 


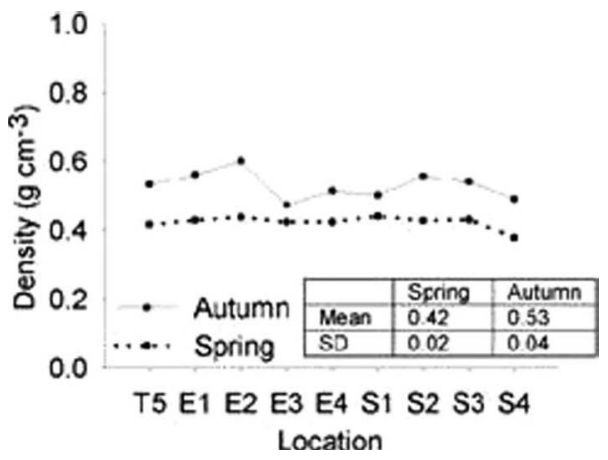

Figure 3. Mean snowpack densities for spring and autmn 2004 for all snow pits 


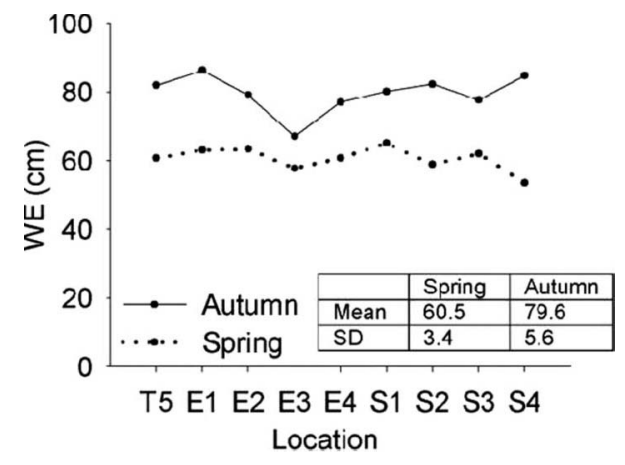

Figure 4. Accumulation (CM w.e.) between end-of-summer 2003 surface layer and spring and autumn 2004 surfaces for all snow pits 